\title{
GRASS GRUB DAMAGE AND MYCORRHIZAL COLONISATION OF GRAPEVINE ROOTSTOCKS
}

\author{
D. C.MUNDY ${ }^{1}$, P. A. ALSPACH ${ }^{2}$ and J. DUFAY ${ }^{3}$ \\ ${ }^{1}$ HortResearch, PO Box 845, Blenheim, New Zealand \\ ${ }^{2}$ HortResearch, PO Box 220, Motueka, New Zealand \\ ${ }^{3}$ Montpellier University, 2 Place Pierre Viala, 34060 MONTPELLIER Cedex 01, \\ France
}

Corresponding author:dmundy@hortresearch.co.nz

\begin{abstract}
Field observations and a grower survey during 2002/2003 indicated that grass grub larvae might be responsible for the death of young grape vines. In November 2003 a pot trial was established to determine whether grass grab larvae feeding caused sufficient root damage to account for observed vine deaths. The experiments also evaluated whether arbuscular mycorrhizal fungi (AMF) colonisation of grape vine roots was affected by grass grub feeding. Grass grub damage was found on the 'below-ground' portion of the trunk and was proportional to the numbers of grubs present. However, root and shoot weight and shoot length were not affected by grub density when measured two months after grubs were introduced. AMF colonization varied between the four rootstocks in the trial, and was higher where grass grubs had been introduced. Further research is required to elucidate the causes of young vine decline in Marlborough.
\end{abstract}

Keywords: grass grub, arbuscular mycorrhizal fungi, grapes, rootstock.

\section{INTRODUCTION}

The use of rootstocks in Marlborough vineyards has become common practice since the discovery of Phylloxera in 1989. A rapid expansion of plantings in Marlborough, from 2095 to 8539 ha during the period from 1994 to 2004 (HortResearch 2004), has been accompanied by a change in the type of rootstock used, as growers increasingly planted at sites that had previously been in arable cropping. In Marlborough, sites able to grow arable cropping are considered relatively high vigour. Accordingly, low vigour rootstocks like 101-14 are widely used to limit vine growth at these sites and achieve balanced vines. A balanced vine produces sufficient leaves to fill the canopy and ripen the fruit. Vines of excessive vigour produce additional leaves that require extra trimming and leaf plucking to maintain disease control and productivity.

Vines grafted onto the rootstock 101-14 often grow poorly in Marlborough and in some cases die the season following planting. Symptoms are similar to young grapevine decline as reported in California (Gubler 1998). Observed contributing factors to decline in California included poor nutrition, lack of adequate irrigation, poor planting techniques, virus-induced incompatibility, nematodes and poor quality planting material, as well as a range of trunk and root pathogens. Decline problems in grapes grown on 101-14 rootstocks may be related to poor colonisation by grape vine arbuscular mycorrhizal fungi (AMF). Colonisation of grapes by AMF has been reported to be important for nutrient uptake and normal growth and development (Menge et al. 1983; Linderman \& Davis 2001; Schreiner 2003). In other plants, AMF confer drought tolerance and resistance to specific pests and diseases (Baumgartner 2003).

A grower survey was initiated in 2003 to identify the probable factors contributing to the poor performance of vines in the Marlborough region. This survey (Mundy 2003) indicated that feeding by native grass grub (Costelytra zealandica) larvae may be 
associated with the observed vine decline, particularly in vineyards recently converted from pasture. Growers reported the presence of this species when digging up vines that had died. There were also visual signs of grass grub damage in cover crops between vines with decline symptoms. This paper reports on a pot trial carried out to confirm that grass grub larvae can damage vine rootstocks and examines whether different rootstocks had varying susceptibilities to grass grub attack. Previous research on grape vine AMF in the district has been conducted only on SO4 rootstocks (Mundy \& Agnew 2004). The pot trial with grass grub also provided an opportunity to examine differences in rootstock performance due to colonisation by AMF.

\section{MATERIALS AND METHODS}

\section{Vines}

Grape vines grafted on one of four rootstocks (101-14, 3309, SO4 and 5C) were potted in planter bags (PB 40) containing a Wairau series deep silt loam soil. The potted plants were placed in a plastic tunnel-house, where the air temperature was controlled using a wet wall (minimum $3.8^{\circ} \mathrm{C}$, maximum $29.1^{\circ} \mathrm{C}$, mean $15.5^{\circ} \mathrm{C}$ ) resulting in environmental conditions similar to those of field grown vines. All vines were watered by hand as required with a minimum of one watering per week.

\section{Pot trial}

Following a three-month establishment phase (December 2003-February 2004 inclusive) grass grub larvae were added to the potted vines at four densities $(0,5,10$ and 20 per plant) for each of four rootstocks. Third instar larvae were collected from an organic apple orchard and handled following the methods of Popay et al. (2003). The experiment was set up as a randomised complete block with 10 replicates. All vines were supplied by Corbans Viticulture Ltd as grafted plants with roots in the same condition as plants typically purchased by growers. Only second grade plants were available for rootstock 5C, but first grade plants were used for the other rootstocks.

\section{Damage assessment}

Plants were destructively sampled eight weeks after the grass grubs were added. The length and dry weight of both roots and shoots were recorded. In addition, the level of damage to the trunk at or below ground level was scored on a 0-4 scale based on the percentage of the circumference damaged, as shown in Table 1. Damage attributed to grass grub larvae resulted in the below-ground trunk sections of vine having sections of bark and vascular tissue missing. Some splitting and fungal damage was also observed on trunks and noted separately.

TABLE 1: System used to categorise trunk damage.

\begin{tabular}{cl}
\hline Score & Percentage of trunk circumference damaged \\
\hline 0 & No damage \\
1 & Up to $25 \%$ \\
2 & $25-50 \%$ \\
3 & $50-75 \%$ \\
4 & Greater than $75 \%$ \\
\hline
\end{tabular}

\section{Presence of arbuscular mycorrhizal fungi}

Root samples were collected from all replicates of the control and highest larval density treatments ( 0 and 20 grubs/plant respectively) and placed into $50 \%$ ethanol prior to staining using the method of Mundy \& Agnew (2004). The roots were cleared by heating for 4 hours in a water bath at $60^{\circ} \mathrm{C}$ with a solution of $10 \% \mathrm{KOH}$. Following rinsing with distilled water, the roots were stained with $0.05 \mathrm{~g} /$ litre Trypan blue in a 1:1:2 solution (by volume) of lactic acid:distilled water:glycerol. The roots were returned to the water bath for an additional 45 minutes before rinsing with $10 \% \mathrm{HCl}$ on cooling. The samples were then rinsed twice with $50 \%$ glycerol before mounting on clean slides with fresh $50 \%$ glycerol. Ten intact root tips from each sample were examined and scored for the presence or absence of AMF. 


\section{Statistical analysis}

Data were subjected to ANOVA. Residual plots were examined to check that the assumptions of uniform variances and normally distributed residuals were appropriate. The relationship between some of the variates was visually explored using scatterplots. All analyses were undertaken in R 1.9.1. Seven vines of rootstock $5 \mathrm{C}$ died during the experiment. The dead vines were evenly distributed over the grass grub treatments, and along with one vine of rootstock 3309 that experienced drought stress (because of a rip in the planting bag resulting in excessive drainage), were omitted from the analyses.

\section{RESULTS}

There were differences between the rootstocks for all root and shoot variates (Table 2). The rootstocks 101-14 and 5C had the shortest roots. In terms of root dry weight, the 101-14 rootstock had the highest and the 5C rootstock the lowest root dry weight. Block and interactions between rootstock and grass grub density were not significant.

The mean root length varied according to grass grub density $(\mathrm{P}=0.049)$, such that plants infested with 20 grass grubs had less root length than plants with 0,5 or 10 grass grubs. The trunk damage score varied with grass grub density $(\mathrm{P}<0.001)$, increasing approximately linearly, but there was no evidence that it differed between the rootstocks $(\mathrm{P}=0.102)$. The damage seen in the 0 grub density treatment can be attributed to splitting and fungal damage.

Differences in AMF levels between rootstocks were observed with $\mathrm{SO} 4$ rootstock having the highest mean colonisation of 9.5 out of 10 tips examined. Rootstock plants with 20 grubs per pot had significantly higher mean colonisation (9.1) compared with plants with no grubs (8.4) (Table 2).

TABLE 2: Root and shoot length $(\mathrm{cm})$ and dry weight (g), trunk damage score and presence of arbuscular mycorrhizal fungi (AMF) for four rootstocks and four grass grub densities (grubs/plant). Values are the mean for each treatment. Standard errors of the difference (SED) and P-values are also presented. There were 126 residual degrees of freedom, except for AMF scores for which there were 56.

\begin{tabular}{|c|c|c|c|c|c|c|}
\hline & \multicolumn{2}{|c|}{ Roots } & \multicolumn{2}{|c|}{ Shoots } & \multirow{2}{*}{$\begin{array}{c}\text { Damage } \\
\text { score }^{1}\end{array}$} & \multirow{2}{*}{$\begin{array}{l}\text { AMF } \\
\text { score }^{2}\end{array}$} \\
\hline & Length & Dry wt & Length & Dry wt & & \\
\hline \multicolumn{7}{|l|}{ Rootstock } \\
\hline $101-14$ & 33.2 & 18.3 & 53.3 & 7.6 & 0.78 & 8.45 \\
\hline 3309 & 46.3 & 15.5 & 99.1 & 12.1 & 0.80 & 8.30 \\
\hline $\mathrm{SO} 4$ & 40.2 & 14.2 & 70.5 & 9.6 & 1.23 & 9.50 \\
\hline $5 \mathrm{C}$ & 33.5 & 8.2 & 48.3 & 5.8 & 1.07 & 8.75 \\
\hline $\mathrm{SED}^{3}$ & 2.4 & 1.2 & 6.04 & 1.05 & 0.216 & 0.439 \\
\hline P-value & $<0.001$ & $<0.001$ & $<0.001$ & $<0.001$ & 0.102 & 0.040 \\
\hline \multicolumn{7}{|l|}{ Grub density } \\
\hline 0 & 39.3 & 15.6 & 70.6 & 9.0 & 0.32 & 8.38 \\
\hline 5 & 40.1 & 13.8 & 65.6 & 8.6 & 0.87 & $-{ }^{4}$ \\
\hline 10 & 40.3 & 13.9 & 70.8 & 8.9 & 1.02 & $-{ }^{4}$ \\
\hline 20 & 34.5 & 13.8 & 67.3 & 9.1 & 1.66 & 9.13 \\
\hline $\mathrm{SED}^{3}$ & 2.4 & 1.2 & 6.04 & 1.05 & 0.216 & 0.323 \\
\hline P-value & 0.049 & 0.341 & 0.774 & 0.956 & $<0.001$ & 0.025 \\
\hline
\end{tabular}

${ }^{1}$ Damage was measured on a scale of $0-4$, with $0=$ no damage and $4=$ greater than $75 \%$ of trunk circumference damaged.

${ }^{2}$ Number of tips out of 10 that contain AMF.

${ }^{3}$ Since the number of plots for each main effect varies (mainly because of death of some $5 \mathrm{C}$ rootstocks), the SEDs also vary. Those given for the rootstock means are for 10 plots, and for the grub density means, the SEDs are for the average number of plots.

${ }^{4}$ Not measured. 


\section{DISCUSSION}

Grass grub larvae can significantly reduce root growth in grapevines grown on different rootstocks. In pasture, grass grub larvae are known to be feeding most actively during February to April. At that stage of the season a young vine is likely to be well established and growing actively, producing new root mass on which the larvae can feed. It is clear from this experiment that grass grubs can damage the below-ground parts of establishing grapevines, although the damage was generally not severe enough to cause vine death. The Californian experience (Gubler 1988) suggests that young vine decline is normally associated with a number of conditions, such as poor nutrition, poor quality planting material and root pathogens. The present research suggests that grass grubs can damage the root systems of establishing vines and may predispose vines to decline, if one or more other predisposing factors are also present.

The vine decline survey (Mundy 2003) indicated that most of the symptomatic vines were planted on 101-14 rootstock. However, damage present on 101-14 rootstocks was similar to that on the other rootstocks. Some physiological differences between rootstocks were apparent, for example, 101-14 vines produced roots with the highest dry weight and the shortest root length regardless of grub density. It is possible that the shorter root length of the 101-14 rootstock may limit recovery from damage such as that caused by grass grubs.

Mycorrhizal colonisation differed between rootstocks and between plants with a relatively high density of grubs and those plants without grubs. Colonisation of rootstock 101-14 was not dissimilar to that of 3309 and 5C. Differences in mycorrhizal colonization of grapevine rootstocks have previously been reported (Linderman \& Davis 2001; Schreiner 2003). The level of AMF detected on all rootstocks in this experiment was higher than previously reported for conventionally grown vines in Marlborough (Agnew et al. 2002). This difference may be due to improved soil moisture in this experiment. Field experiments conducted using mulch to increase soil moisture also resulted in higher levels of AMF compared with those on conventionally grown vines (Mundy \& Agnew 2004). Herbicides and other viticultural inputs may also reduce soil microbe numbers (Weckert 2002). The potted vines received no herbicides, fungicides or fertilisers during the experiment, which could also account for the comparatively higher levels of AMF. The increased levels of AMF on vine roots with grass grubs is worthy of additional investigation. The grass grubs may have selectively fed on root tips without AMF present or the plant may have responded to damage to the root system by forming more mycorrhizal associations.

In conclusion, grass grub damage alone does not explain the level of mortality observed in Marlborough for vines on 101-14 rootstocks. The 101-14 rootstock was not more susceptible to grass grub damage and did not have a differential level of AMF colonisation, suggesting that, for these factors at least, this rootstock is not more predisposed to young vine decline than any other rootstock used in Marlborough. Further research is required to elucidate the causes of young vine decline in this region.

\section{ACKNOWLEDGEMENTS}

The pot trial to investigate grass grub damage was funded by Corbans Viticulture Ltd. The investigation of the AMF status of the vines was made possible by the Marlborough Wine Research Centre who sponsored Julien Dufay during his two-month visit to New Zealand. Margaret Roberts and Bruce West assisted with the field work for this project. David Logan provided expertise on scarab beetles and insight into how to manage the grubs.

\section{REFERENCES}

Agnew R, Mundy D, Spiers M 2002. Mulch for sustainable production. HortResearch, Blenheim. 48 p. http://www.hortresearch.co.nz/files/2002/mulch.pdf (Accessed 10 May 2005).

Baumgartner K 2003. Encouraging beneficial AM fungi in vineyard soil. Practical Winery \& Vineyard January/February: 57-60. 
Gubler D 1998. Investigation into grapevine decline continues. California Grower 22(11): 25-26.

HortResearch 2004. New Zealand Horticulture Facts \& Figures 2004. Horticulture Facts and Figures series. HortResearch, Auckland. http://www.hortresearch.co.nz/files/ aboutus/factsandfigs/ff2004.pdf (Accessed 10 May 2005).

Linderman RG, Davis EA 2001. Comparative response of selected grapevine rootstocks and cultivars to inoculation with different mycorrhizal fungi. American Journal for Enology and Viticulture 52(1): 8-11.

Menge J, Raski D, Lider L, Johnson E, Jones N, Kissler J, Hemstreet C 1983. Interactions between mycorrhizal fungi, soil fumigation and growth of grapes in California. American Journal for Enology and Viticulture 34(2): 117-121.

Mundy D 2003. Performance of grapevines grown on 101-14 rootstock in Marlborough. The Australian \& New Zealand Grapegrower \& Winemaker 477: 70-75.

Mundy D, Agnew R 2004. Methods for the detection of fungi in New Zealand vineyard soils after a single application of mulch. In: Keller KO, Hall B ed. 3rd Australasian Soilborne Diseases Symposium. Barossa, South Australia. Pp. 104-105.

Popay AJ, Townsend RJ, Fletcher LR 2003. The effect of endophyte (Neotyphodium uncinatum) in meadow fescue on grass grub larvae. New Zealand Plant Protection 56: $123-128$.

Schreiner RP 2003. Mycorrhizal colonisation of grapevine rootstocks under field conditions. American Journal of Enology and Viticulture 54(3): 143-149.

Weckert M 2002. Vineyard microbial soil health. The Australian \& New Zealand Grapegrower \& Winemaker 464: 21-24. 